\title{
Florida Homeowner Herbicide Guide: Considerations, Applications, and Selection ${ }^{1}$
}

\author{
Chris Marble ${ }^{2}$
}

\section{Introduction}

While some people opt for professional lawn maintenance companies, some homeowners may wish to perform their own landscape pest control in order to save money or to have more control of what is applied, or simply because they enjoy it. This EDIS publication is for Florida gardeners, horticulturalists, and homeowners who want to utilize herbicides to control weeds in their landscape. This publication discusses common herbicides available at retail stores and how homeowners can use them safely and effectively.

This publication provides information and general management recommendations for a variety of common weed species found throughout home landscapes in Florida. For a species-specific weed identification guide or information on weed control in turfgrass, visit the EDIS Weed Control (http://edis.ifas.ufl.edu/topic_weeds) directory.

\section{Considerations for the Do-lt- Yourself Homeowner}

Before applying a pesticide of any kind, it is extremely important to first educate yourself on the chemical(s) you are using. Professional pesticide applicators are required to complete hours of training each year in order to keep their pesticide licenses and legally apply pesticides. They must also take exams to ensure they are properly trained to identify pests, apply pesticides correctly, and know how pesticides work, among other topics.

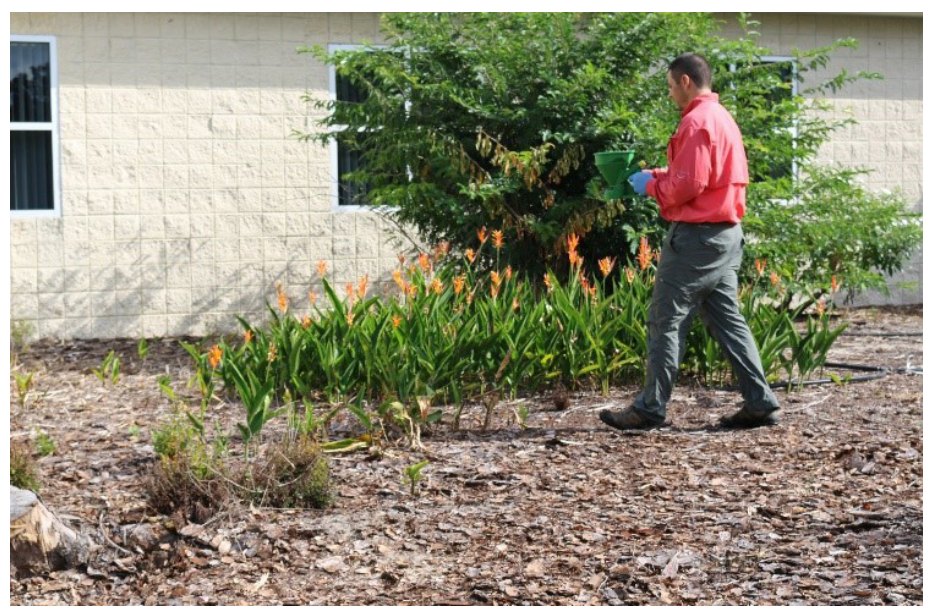

Figure 1. When applying herbicides, be sure to wear long sleeves and pants, closed-toe shoes, socks, gloves and any other required Personal Protective Equipment (PPE) listed on the label to avoid potential exposure.

Credits: Caroline Warwick, UF/IFAS

Homeowners commonly cause significant and/or irreversible damage to their landscapes by misapplying herbicides and ignoring or not reading product labels. Reading and following all label instructions is required by law, but reading pesticide labels should be the bare minimum amount of

1. This document is ENH1311, one of a series of the Environmental Horticulture Department, UF/IFAS Extension. Original publication date August 2019. Visit the EDIS website at https://edis.ifas.ufl.edu for the currently supported version of this publication.

2. Chris Marble, assistant professor, Environmental Horticulture Department, UF/IFAS Mid Florida Research and Education Center, Apopka, FL 32703.

The use of trade names in this publication is solely for the purpose of providing specific information. UF/IFAS does not guarantee or warranty the products named, and references to them in this publication do not signify our approval to the exclusion of other products of suitable composition. All chemicals should be used in accordance with directions on the manufacturer's label. Use herbicides safely. Read and follow directions on the manufacturer's label.

The Institute of Food and Agricultural Sciences (IFAS) is an Equal Opportunity Institution authorized to provide research, educational information and other services

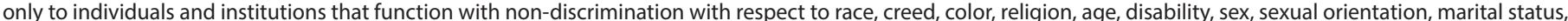

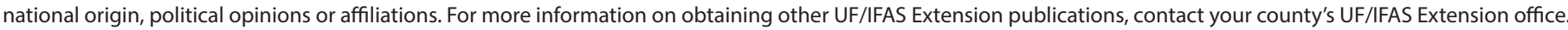
U.S. Department of Agriculture, UF/IFAS Extension Service, University of Florida, IFAS, Florida A \& M University Cooperative Extension Program, and Boards of County Commissioners Cooperating. Nick T. Place, dean for UF/IFAS Extension. 
training that a person completes before starting to conduct their own pest control. Homeowners in Florida can visit their local county Extension office for additional training on how to use pesticides correctly and effectively.

Note also that homeowners will not have access to the same products that professional pest control companies will have. Some of the most effective products for specific pest problems may not be available to those without a pesticide license or may only be available in large (and expensive) quantities because they are primarily used by professional applicators.

\section{Applying Herbicides Herbicide Classifications}

Herbicides can be broadly classified as preemergence or postemergence depending on time of application. Preemergence herbicides are applied to the soil and kill weeds as they germinate. Postemergence herbicides are applied to weeds after they emerge. Postemergence herbicides can be further classified as either contact or systemic. Contact herbicides are not translocated within the plant and only affect the part of the plant that they contact, which means that they will work on aboveground tissues that are contacted by the spray. Systemic herbicides are translocated within the plant and generally are effective on plant roots. Contact herbicides typically cause symptoms to appear much more rapidly than systemic herbicides. However, systemic herbicides offer advantages: First, they are generally more effective on perennial weeds that have extensive root systems or are spreading via rhizomes and/ or stolons. Second, thorough coverage is not as critical with systemic herbicides as with contact herbicides. While better control will be achieved with thorough coverage, systemic herbicides can move through plant tissues and may work on smaller weeds even if the weed is not thoroughly contacted by spray. It is also important to note that for these reasons, systemic herbicides are much less forgiving if ornamentals are inadvertently sprayed, and those plants may not recover. Most woody ornamentals can eventually recover if they are accidentally sprayed with a contact herbicide.

Herbicides can further be classified as selective or nonselective. Selective herbicides are only active on a particular type of weed, such as broadleaf weeds, while a non-selective herbicide is active on most plants, such as broadleaves, grasses, or sedges.

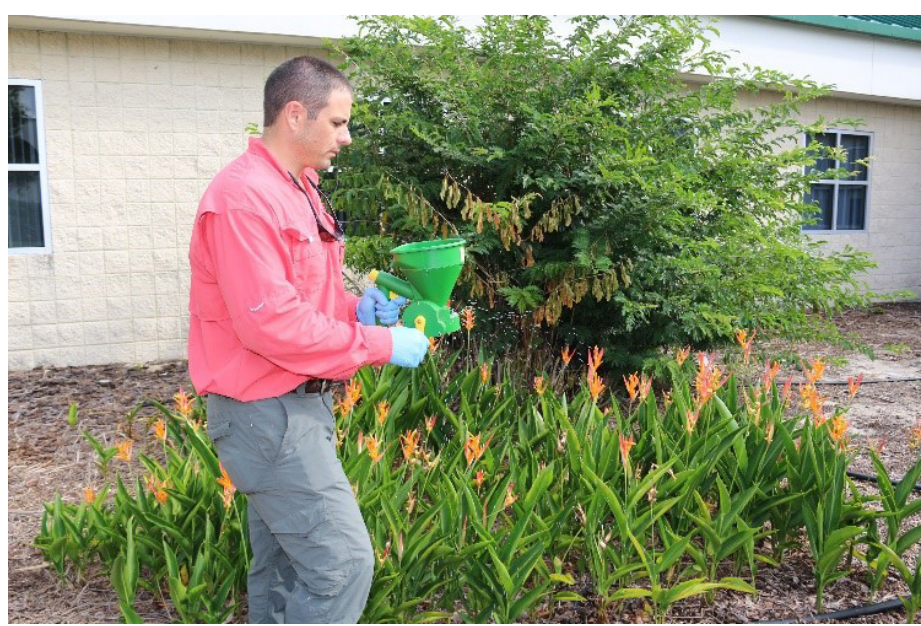

Figure 2. When applying herbicides, be sure to walk at the same pace through the treatment area to ensure even applications. Credits: Caroline Warwick, UF/IFAS

\section{Herbicide Combinations}

Herbicide products commonly contain more than one active ingredient. Combining two or more active ingredients may be done for several reasons. The most common reason is to increase the spectrum of control, meaning that more weeds will be controlled by combining two or more herbicides together. For example, two or more broadleaf herbicides may be combined to control different types of broadleaf weeds, or herbicides effective on nutsedge may be added to control sedge weeds.

Contact herbicides are also commonly added to systemic herbicides. It may take 7 to 10 days or longer for symptoms to appear following application of systemic herbicides, such as glyphosate. Because contact herbicides cause symptoms to appear quickly, they are often added in small quantities to systemic herbicides to make symptoms appear more rapidly. These mixtures have been reported to increase the level of control of some weed species. However, as the contact herbicide acts very rapidly, it may reduce uptake of the systemic herbicide, which takes longer to work. Depending on the weed species, these mixtures may have no effect on weed control (Wehtje et al. 2009) or could actually decrease the long-term level of control (Wehtje et al. 2008).

\section{Common Herbicides Available to Homeowners}

Walking through a local garden center or retail store, one would think they have dozens of herbicides to choose from; however, selecting the best product can be a daunting task for those unfamiliar with active ingredients. In reality, you will most likely find that there are fewer than 10 different herbicidal active ingredients used in all the different products, and many products are very similar or the exact 
same thing but made by different manufacturers. A list of the most common homeowner herbicides is included in Tables 1 and 2, and these herbicides are discussed below.

\section{Postemergence Herbicides}

Postemergence herbicides are usually sold as liquids or sprayable formulations. They may be sold as concentrates, meaning they must be diluted with water prior to use, or sold as a ready-to-use product that is already diluted. Postemergence herbicides may also be sold as granular formulations and applied with a spreader, usually in herbicide + fertilizer or "weed-n-feed" products. Product labels contain all of the information needed to use the herbicide safely and effectively. A list of common postemergence herbicides marketed toward homeowners is available in Table 1.

\section{Turfgrass Herbicides 2,4-D AND COMBINATIONS}

One of the most common broadleaf herbicides is 2,4-D.

2,4 -D is a systemic herbicide that works by causing uncontrolled cell division in susceptible plants (broadleaf plants). It is one of the most commonly used herbicides by homeowners for broadleaf weed control in turf. It is often combined with other broadleaf herbicides such as mecoprop or dicamba, which are also broadleaf herbicides. These herbicides are labeled for use in turfgrass such as zoysia, bahiagrass, bermudagrass, and centipede grass, depending upon the label, and should not be applied to planting beds.

\section{ATRAZINE}

Atrazine is one of the most common postemergence herbicides used in St. Augustine turfgrass. It is a systemic herbicide and is effective on many broadleaf weeds. It may be sold as a liquid, sprayable formulation or used in weed$\mathrm{n}$-feed products. Damage can occur when it applied during warm temperatures $\left(>85^{\circ} \mathrm{F}\right)$.

\section{CARFENTRAZONE}

Carfentrazone is a contact postemergence herbicide that is often added to other herbicides or used alone to control broadleaf weeds in turfgrass including bermudagrass, bahiagrass, zoysia, and St. Augustine, depending upon the specific product label. Misapplication or application during periods of stress can cause turf discoloration.

\section{QUINCLORAC}

Quinclorac is a postemergence herbicide that may be included in weed-n-feed or other herbicide mixtures. Quinclorac has some activity on certain broadleaf weeds such as black medic (Medicago lupuline) or clovers (Trifolium spp.), but is primarily included in homeowner products for grassy weed control, such as crabgrass (Digitaria spp.). Products containing quinclorac are typically labeled for use in bermudagrass and zoysia lawns.

\section{PENOXSULAM}

Penoxsulam is a systemic postemergence herbicide often added to lawn herbicides to increase control of certain broadleaf weeds such as dollarweed (Hydrocotyle spp.), eclipta (Eclipta alba), some dayflower species (Commelina spp.), and others.

For more information on homeowner herbicides for weed control in home lawns, see ENH884, Weed Management Guide for Florida Lawns (http://edis.ifas.ufl.edu/ep141).

\section{Brush-Control Herbicides}

Brush-control herbicides often contain glyphosate, triclopyr, or some combination of these two products. 2,4-D may also be added in some products. These herbicides are often marketed as brush or vine killers. Triclopyr is a broadleaf herbicide and is very effective on many woody broadleaf weeds and invasive plants and vines. Care should be taken to avoid accidental contact to desirable trees and shrubs with these products because they can be very damaging even to large plants.

\section{Sedge Herbicides}

Sedge herbicides may be sold alone or added to other products to increase sedge control in turfgrass or other landscape areas. Many of these products are labeled for use in planting beds depending on what other herbicides are mixed with them. For information on sedge herbicides specific to turfgrass use, consult ENH884, Weed Management Guide for Florida Lawns (http://edis.ifas.ufl.edu/ ep141). Below are the four most common sedge herbicides.

1. Bentazon-a postemergence herbicide often used for yellow nutsedge (Cyperus esculentus) control. Bentazon has activity on some broadleaf weeds, such as dayflower, groundsel (Senecio vulgaris), and purslane (Portulaca oleracea), but has no activity on grasses. 
2. Halosulfuron-a systemic postemergence herbicide used primarily for control of yellow and purple nutsedge (Cyperus rotundus) and other sedge species.

3. Imazaquin - a systemic postemergence herbicide used for sedge control and for control of dollarweed (Hydrocotyle spp.) and certain other broadleaf weeds, such as black medic, eclipta, Carolina geranium (Geranium carolinianum), and others in turfgrass.

4. Sulfentrazone-a postemergence herbicide used for sedge control, but which can also provide control or suppression of certain broadleaf weeds, such as spotted spurge (Euphorbia maculata).

\section{Grass Herbicides (Graminicides)}

Several graminicides are available to homeowners and often sold as "grass killers." These graminicides include fenoxaprop, fluazifop, clethodim, and sethoxydim. All of these are postemergence herbicides that control annual and perennial grasses. When used alone, they can be applied in planting beds containing broadleaf plants that are included as safe on the product label. It should be noted that some products sold as "grass and weed killers" do not contain a graminicide but may only contain a non-selective herbicide such as glyphosate. "Grass killer" may be in the name only to discourage people from applying it to their lawns.

\section{Non-Selective Herbicides GLYPHOSATE AND GLYPHOSATE COMBINATIONS}

Glyphosate is the top-selling pesticide worldwide and is available in most retail garden centers and big-box store chains. Glyphosate may be sold in ready-to-use form, usually diluted to around $2 \%$ glyphosate, or in concentrate forms up to $40 \%$ glyphosate, which must be diluted with water prior to spraying. Glyphosate is a non-selective herbicide and is effective on most weeds. It can be used to spot-spray weeds in planting beds, hardscapes, and other areas. It is not absorbed by plant roots but can be absorbed by green tissues such as bark or stems and translocated throughout the plant. Several herbicides are often added to glyphosate and marketed to homeowners for different purposes. Some of the herbicides often added to glyphosate include:

\footnotetext{
1. Diquat - a non-selective contact herbicide. It is often added to glyphosate to speed results as symptoms appear quickly. It is only absorbed through green tissues and is not absorbed by plant roots.
}

2. Pelargonic acid - a contact herbicide often added to glyphosate for the same reasons diquat is added. It is only absorbed through green tissues and stems and is not absorbed by plant roots.

3. Imazapyr, Imazapic, Imazethapyr - these herbicides are classified as acetolactate synthase (ALS) inhibitors and are absorbed by both shoots and plant roots. They are often added to herbicides that provide "total vegetation control" or "year-long" control. They are intended for use in hardscapes and in areas where no ornamental or desirable plants are growing or will be grown. Application to the root zone of plants can be lethal in some cases, especially when high rates are applied. Death of trees, shrubs, and other ornamental plants is often attributed to misuse of products containing these active ingredients. Symptoms generally begin as a general chlorosis (yellowing), then progress to some possible growth distortion (small, stunted leaves), browning, and death.

4. Indaziflam - a preemergence herbicide that provides control of broadleaf and grassy weeds from seed.

\section{GLUFOSINATE}

Glufosinate is a non-selective herbicide that is minimally translocated, and therefore it is often considered a contact herbicide. Glufosinate may be added to other products or sold alone to homeowners. It controls a wide variety of grassy and broadleaf weeds. Glufosinate is often used to control weeds that are difficult to control with glyphosate or that are resistant to glyphosate.

\section{ORGANIC AND/OR CONTACT HERBICIDES}

Many people wish to use organic or "natural" herbicides in their home landscape. Organic or "natural" products that are available to homeowners include citrus oils, oregano oil, acetic acid (vinegar) products, ammonium nonanoate, and other products. Some copper- or iron-based products may also be available for moss or algae control. All these products are contact herbicides and are more effective on small annual weeds. They typically provide poor control of perennial weeds, especially once they become established.

\section{Homeowner "Concoctions"}

Household vinegar, dish detergent, ammonia, salt, bleach and other household items are often mixed in different proportions and used for weed control by homeowners. These items are typically used by those wanting to either save money or avoid using synthetic herbicides for fear that they are causing environmental damage. There are several problems associated with these mixtures. First, these 
mixtures are usually only effective on small annual weeds. While browning or burning is usually evident, repeated applications are needed for long-term control, and perennial weeds will not be controlled unless they are very small. Secondly, in many cases these mixtures are more expensive per application than synthetic herbicides. A common recommendation calls for one gallon of vinegar, one cup of table salt, and a tablespoon of dish detergent. This might cost around $\$ 3.00$, whereas a one-gallon solution of glyphosate at a $1.5 \%$ concentration would cost approximately $\$ 0.60$ or less. Lastly and most importantly, thousands of hours of research are conducted before a product is labeled for use as a pesticide. This information includes proper rates for weed control, mixing/application instructions, and how to protect yourself, others, and the environment. This critical information is not available on household products that are not intended to be used as pesticides. If someone wants to avoid using synthetic herbicides, many alternatives are available, are labeled for use as herbicides, and include information on how to use them properly and effectively.

\section{Preemergence Herbicides}

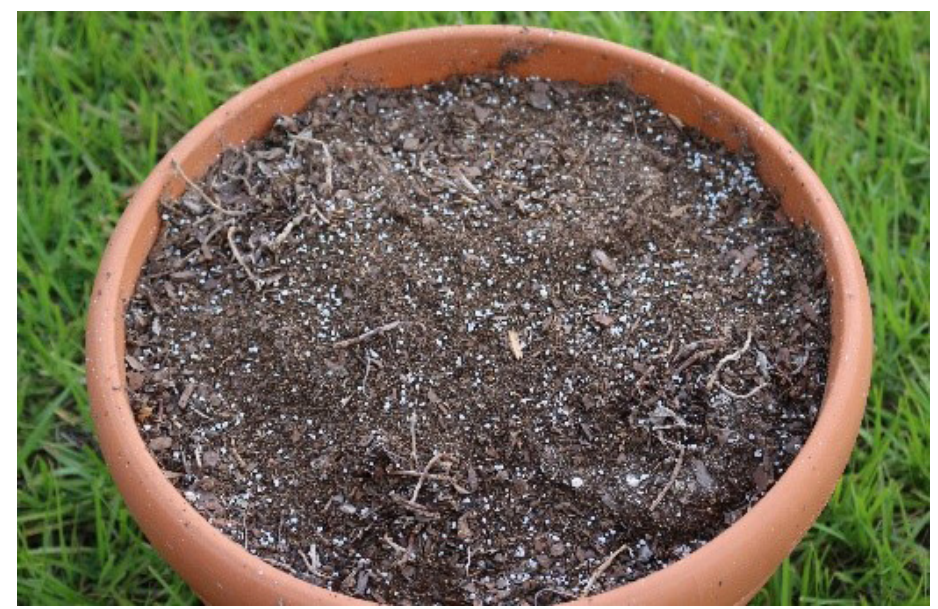

Figure 3. Granular preemergence herbicide is applied on top of the soil to prevent weeds from growing.

Credits: Caroline R. Warwick, UF/IFAS

Similar to postemergence herbicides, preemergence herbicides may be in granular or spray-applied formulations, but most products intended for homeowner use are in granular form. These preemergence herbicides may also be added as components of weed-n-feed products or in mixtures with other postemergence herbicides, such as glyphosate. Products that are commonly called "weed preventers" are preemergence herbicides. A list of the most common preemergence herbicides available to homeowners is included in Table 2 .

\section{Dinitroanaline Herbicides (DNAs)}

The most common group of preemergence herbicides available to homeowners are dinitroanline herbicides. This group includes common herbicides such as pendimethalin, prodiamine, benfluralin (also called benefin), oryzalin, and trifluralin. Dithiopyr is not technically a dinitroanline herbicide but works in a similar manner. These preemergence herbicides are primarily used to control grassy weeds germinating from seed (such as crabgrass species) but also control some broadleaf weeds as well.

These herbicides are commonly labeled for use in planting beds and/or turf. Because preemergence herbicides will only be effective if applied before seed germination, proper timing is critical. Information on properly timing preemergence herbicide applications is available in the EDIS publication ENH884, Weed Management Guide for Florida Lawns (http://edis.ifas.ufl.edu/ep141). None of these herbicides will provide season-long control. These herbicides generally start to lose their effectiveness anywhere from 6 to 10 weeks after they are applied. Therefore, additional applications are needed before control begins to break. Each herbicide label will contain information on how many applications are allowed, application intervals, and rates that should be used.

These products may be sold alone, come preinstalled on mulch or weed fabric, used in weed-n-feed mixtures, or added with other herbicides. They may also be combined together, such as trifluralin, which is commonly combined with benefin. These herbicides are usually yellow or orange in color and can stain driveways and hardscapes.

\section{NAPROPAMIDE}

Napropamide is a preemergence herbicide that is not widely available but may be found in some homeowner products. Herbicides containing napropamide may be labeled for use in some garden plants, bedding plants, or other areas. Napropamide is primarily used for grassy weed control.

\section{ISOXABEN}

Isoxaben is used for preemergence control of broadleaf weeds. It is often combined with herbicides that are more effective on grasses, such as trifluralin or prodiamine.

\section{INDAZIFLAM}

Indaziflam is a broad-spectrum preemergence herbicide that provides preemergence control of broadleaf and grassy weeds. It is commonly added to other postemergence herbicides or in weed-n-feed products. 


\section{CORN GLUTEN MEAL}

Corn gluten meal (CGM) is often promoted for use as an organic preemergence herbicide. CGM will offer preemergence control of several broadleaf and annual weeds germinating from seed (Bingaman and Christians 1995) for several weeks, but not all weeds will be controlled. Note that CGM also contains a considerable amount of nitrogen, which should be taken into account when determining yearly fertilizer needs for landscape plants or turf. CGM will not control established weeds, and the added nitrogen could cause increased growth of existing weeds. Another consideration is that high rates (around 30 lb per $1,000 \mathrm{ft}^{2}$ of CGM as opposed to 2.3 to $4.6 \mathrm{lb}$ per 1,000 $\mathrm{ft}^{2}$ for common synthetic herbicides) are recommended, which increases the difficulty of transporting and spreading the material. While disadvantages exist, CGM could be an option for some homeowners who do not want to use conventional preemergence herbicides.

\section{Selecting the Right Herbicide}

The best herbicide option will depend on: 1) the weed species that you are targeting; 2) the use site (ornamental bed, turfgrass, hardscape, etc.); 3 ) the cost and amount of product; and 4) the preferred application method (granular, spray concentrate, ready-to-use, etc.). Consider the following when selecting an herbicide:

\section{Never underestimate the importance of weed identification.}

\begin{abstract}
Always identify the weed species you are trying to control before making an application. Homeowners can contact their local county Extension office for help identifying weed species. Failing to do so will often yield less-than-satisfactory results because no one herbicide will control all weed species. Furthermore, even if an herbicide is marketed as effective on broadleaf weeds, that does not mean it will control all broadleaf weeds. The same is true for grass herbicides and sedge herbicides. Product labels contain information on which weeds are controlled or may have specific instructions on how to control certain weed species; if the weed is not identified first, these instructions cannot be followed and poor control may result.
\end{abstract}

\section{Right Product, Right Place}

When applying herbicides, be sure to use products only on the sites for which they are labeled. Herbicide labels give instructions stating where it can be applied and which turfgrasses or ornamentals are safe for application. Application to ornamental species or turfgrass that are not on the label can result in severe injury or death to desirable species. The use site is also critically important to follow. First, it is the law-it is illegal to use a pesticide inconsistent with its labeling. Secondly, nontarget plants can be significantly damaged if a product is applied to a nonapproved site. For example, there have been instances where homeowners have applied herbicides labeled for use in bahiagrass pastures to bahiagrass lawns. While the bahiagrass was unaffected, there was significant damage to trees, shrubs, and other ornamental plants in many of these cases.

\section{Consider the cost.}

Consider the cost, the amount needed for your landscape, and the amount you will have to buy. Most of the herbicides discussed in this article are available at big box retailers and will be in quantities suitable for home landscapes. However, many herbicides (and other pesticides) are available to homeowners for purchase at agricultural supply stores or online via do-it-yourself pest-control websites. Homeowners who purchase herbicides from these sources will have more options but should consider how much of the herbicide they will need for their landscape and how they will store and secure the products. These herbicides are sold in commercial quantities, and one package or bottle may be enough to treat several acres. Homeowners with large areas to maintain may be able to utilize large quantities, but often these herbicides will spoil before they can be used, creating significant disposal issues. A comprehensive guide to pesticides labeled for use in landscapes is available in the 2017 Southeast Pest Management Guide for Nurseries and Landscape Plantings (https://content.ces.ncsu.edu/ southeastern-us-pest-control-guide-for-nursery-crops-andlandscape-plantings).

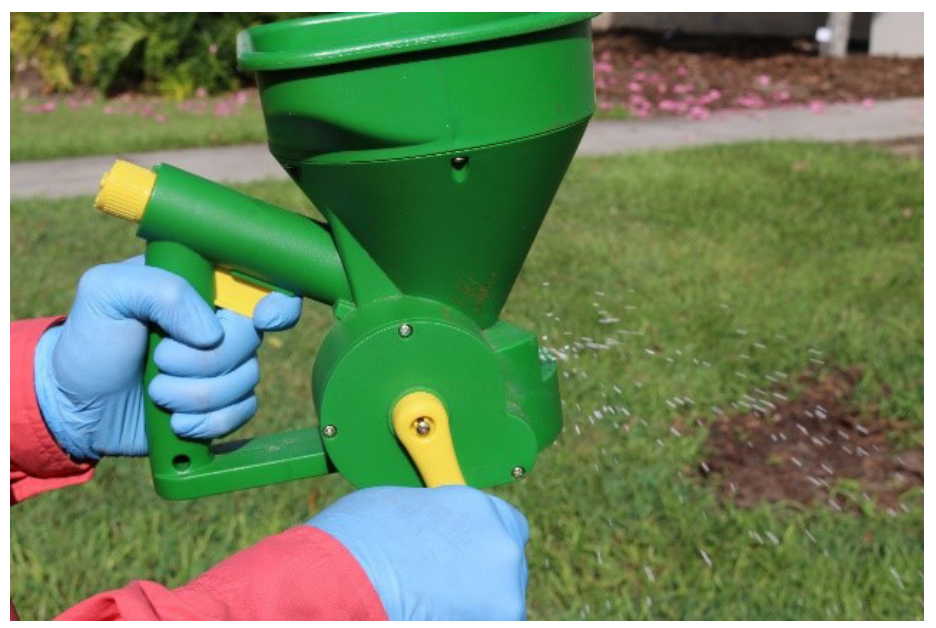

Figure 4. Applicators, like the one pictured here, spread product evenly throughout the landscape.

Credits: Caroline Warwick, UF/IFAS 


\section{Application methods matter.}

What is the preferred application method? Many herbicides are available as either a granular or a spray-applied formulation. The best formulation for a particular situation will depend on the application equipment available, such as backpack sprayers or rotary spreaders, and the comfort level of the applicator with each method. The most important aspect of herbicide application is properly calibrating whatever type of equipment you are using so that the correct amount of product is applied. For information on calibrating single-nozzle backpack sprayers, refer to EDIS publication SS-AGR-108, Single-Nozzle Backpack or ATV Sprayer Calibration (http://edis.ifas.ufl.edu/wg217).

Options are available to homeowners who wish to use herbicides to manage weeds in their landscapes. When choosing an herbicide, always look at the active ingredients and read the entire label to ensure that herbicide will work for your situation. Many mistakes are made by only reading promises of "quick kills" or "prevention up to 6 months" and ignoring fine print and detailed instructions. The most valuable time spent conducting weed management is the few minutes it takes to read the product label. The label will provide all the information you need to use that herbicide safely and effectively.

\section{References}

Bingaman, B. R., and N. E. Christians. 1995. "Greenhouse screening of corn gluten meal as a natural control product for broadleaf and grass weeds." HortScience 30:1256-1259.

Wehtje, G., J. E. Altland, and C. H. Gilliam. 2008. "Interaction of glyphosate and diquat in ready-to-use weed control products." WeedTechnology 22:472-476.

Wehtje, G., J. E. Altland, and C. H. Gilliam. 2009. "Interaction of glyphosate and pelargonic acid in ready-to-use weed control products." WeedTechnology 23:544-549. 
Table 1. Common postemergence herbicides available to homeowners at retail stores and garden centers. ${ }^{1}$

\begin{tabular}{|c|c|}
\hline Herbicide & Information and Uses \\
\hline 2,4-D & \multirow{3}{*}{$\begin{array}{l}\text { These herbicides provide broadleaf weed control in turf. They are often combined together or with other } \\
\text { herbicides and used as a component in many weed-n-feed products. }\end{array}$} \\
\hline Dicamba & \\
\hline Mecoprop & \\
\hline Atrazine & Broadleaf weed control in turf, primarily St. Augustine turfgrass. Often used in weed-n-feed products. \\
\hline Carfentrazone & $\begin{array}{l}\text { A contact broadleaf herbicide often used in combination with other herbicides. May be a component of } \\
\text { "moss killers." }\end{array}$ \\
\hline Quinclorac & $\begin{array}{l}\text { May be included in weed-n-feed products but not commonly available. Primarily added to other herbicides } \\
\text { for crabgrass control. }\end{array}$ \\
\hline Penoxsulam & $\begin{array}{l}\text { A systemic broadleaf postemergence herbicide added to other herbicides or in weed-n-feed mixtures to } \\
\text { broaden spectrum of control. }\end{array}$ \\
\hline Triclopyr & $\begin{array}{l}\text { Systemic broadleaf herbicide. Often the active ingredient in brush or vine killers. May be mixed with } \\
\text { glyphosate in some of these products. }\end{array}$ \\
\hline Glyphosate & $\begin{array}{l}\text { Systemic and non-selective herbicide. Sold alone or in combination with many other postemergence } \\
\text { herbicides. Will control most weeds. }\end{array}$ \\
\hline Bentazon & Control sedge and some broadleaf weeds. Primarily used for yellow nutsedge control. \\
\hline Halosulfuron & Used for sedge control including yellow and purple nutsedge. \\
\hline Imazaquin & Used to control sedges, dollarweed, and certain other broadleaf weeds. \\
\hline Sulfentrazone & $\begin{array}{l}\text { Used to control sedges either alone or as a component of weed-n-feed products or other postemergence } \\
\text { herbicides. }\end{array}$ \\
\hline Fenoxaprop & \multirow{4}{*}{$\begin{array}{l}\text { Systemic postemergence grass herbicides (graminicides). These may be used alone or combined with other } \\
\text { products to enhance grass control. When used alone, they are often labeled for use in planting beds. }\end{array}$} \\
\hline Fluazifop & \\
\hline Clethodim & \\
\hline Sethoxydim & \\
\hline Diquat & \multirow{2}{*}{$\begin{array}{l}\text { Non-selective contact herbicides that provide fast results. Often added to glyphosate or other products to } \\
\text { make results appear more rapidly. }\end{array}$} \\
\hline Pelargonic acid & \\
\hline Imazapyr & \multirow{3}{*}{$\begin{array}{l}\text { Soil-sterilant-type herbicides that may be mixed with glyphosate or other herbicides that promise long- } \\
\text { lasting control or total vegetation management. These are intended for use around hardscapes and other } \\
\text { areas in which no desirable plants are growing. }\end{array}$} \\
\hline Imazapic & \\
\hline Imazethapyr & \\
\hline Glufosinate & $\begin{array}{l}\text { A non-selective herbicide that is minimally translocated. Often used to control weeds that are not controlled } \\
\text { with glyphosate. }\end{array}$ \\
\hline Organic herbicides & $\begin{array}{l}\text { Many postemergence herbicides are available and marketed as "organic."These may include citrus oils, } \\
\text { oregano oil, acetic acid (vinegar) products, ammonium nonanoate, fatty acid soaps, iron products, and } \\
\text { others. These are contact-action herbicides and are more effective on small, actively growing annual weeds } \\
\text { and not as effective on perennial weeds. }\end{array}$ \\
\hline \multicolumn{2}{|c|}{$\begin{array}{l}{ }^{1} \text { Please note that which herbicides are available to homeowners constantly evolves, and that at time of publication (August } 2019 \text { ), this was } \\
\text { the most accurate selection available on the market. These notes are for informational/educational purposes only and are not a substitute } \\
\text { for reading and following all label directions and precautions. The applicator is responsible for using each herbicide according to the } \\
\text { manufacturer recommendations. Read and follow the label instructions-it is the law. }\end{array}$} \\
\hline
\end{tabular}


Table 2. Common preemergence herbicides available to homeowners at retail stores and garden centers.

\begin{tabular}{|c|c|}
\hline Herbicide & Notes:** \\
\hline Pendimethalin & \multirow{3}{*}{$\begin{array}{l}\text { Offers preemergence control of many annual grass weeds (including crabgrass) and some broadleaf } \\
\text { weeds. }\end{array}$} \\
\hline Prodiamine & \\
\hline Dithiopyr & \\
\hline Benfluralin (benefin) & Provides control of some annual grass weeds and some broadleaf weeds. Often combined with trifluralin. \\
\hline Oryzalin & $\begin{array}{l}\text { Control of annual grasses and some broadleaf weeds. Typically not sold alone but used in combination } \\
\text { with other herbicides or in weed-n-feed products. }\end{array}$ \\
\hline Trifluralin & $\begin{array}{l}\text { Provides control of some annual grasses and sedges. Often used in flower beds and safe around many } \\
\text { ornamentals, but provides weaker weed control. }\end{array}$ \\
\hline Napropramide & Rarely available but may be in herbicides labeled for use in flower beds or gardens. \\
\hline Isoxaben & $\begin{array}{l}\text { Provides control of broadleaf weeds. Often combined with other preemergence herbicides that offer } \\
\text { control of annual grasses (trifluralin, prodiamine, etc.). }\end{array}$ \\
\hline Indaziflam & $\begin{array}{l}\text { Provides control of broadleaf and grassy weeds from seed. Usually added as a preemergence herbicide in } \\
\text { weed-n-feed products or in ready-to-use mixtures with glyphosate. }\end{array}$ \\
\hline Corn gluten meal & $\begin{array}{l}\text { An organic preemergence option that controls certain broadleaf and grassy weeds from seed. Will not } \\
\text { provide long-term control and may be difficult and/or expensive to apply. }\end{array}$ \\
\hline
\end{tabular}

